\title{
Analisis Pengaruh Kompensasi Dan Kepimimpinan Terhadap Disiplin Kerja Pegawai Pada Badan Lingkungan Hidup Dan Kebersihan Kabupaten Aceh Tenggara
}

\author{
Analysis of the Effect of Compensation and Leadership on Employee Work Discipline \\ at the Environment and Hygiene Agency of Southeast Aceh Regency
}

\author{
Ardi Hirmansah \\ Fakultas Ekonomi, Program Studi Manajemen, Universitas Gunung Leuser Aceh, \\ Jalan Iskandar Muda No. 1 Babussalam Kutacane 24651 Telp. (0629) 523281. Fax (0629) 523281 \\ e-mail: ardihirmansah36@gmail.com
}

\begin{abstract}
Di era globalisasi saat ini, Manajemen sumber daya manusia pada umumnya sangat di butuhkan untuk memperoleh peningkatan perkembangan karyawan, hubungan kerja yang serasi di antara para karyawan diharapkan akan meningkatkan produktivitas kerja, dengan adanya sumber daya yang baik, maka kompetensi yang baik akan tercipta, sehingga kinerja yang baik pula akan ikut serta dalam organisasi tersebut. Dalam hal ini disiplin dan ketegasan pemimpin dalam menegakkan peraturan yang baik akan mencerminkan sikap dan tanggung jawab seorang pengawai dalam menjalankan tugas-tugas yang diberikan padanya. Penelitian ini menggunankan metode kuantitatifdengan teknik pengumpulan data melalui penyebaran kuesioner dan wawancara dan kemudian menggunakan uji analaisis regresi berganda untuk mendapatkan jawawaban hipotesi yang ditentukan dengan jumlah sample 68 orang. Ada banyak faktor-faktor yang mempengaruhi disiplin kerja diantaranya kompensasi dan kepemimpinan.
\end{abstract}

Kata Kunci : Kompensasi, Kepemimpinan, Disiplin Kerja

\begin{abstract}
In the current era of globalization, human resource management is generally very much needed to obtain an increase in employee development, harmonious working relationships among employees are expected to increase work productivity, with good resources, good competencies will be created, so that good performance will also participate in the organization. In this case the discipline and firmness of the leader in enforcing good regulations will reflect the attitude and responsibility of an employee in carrying out the tasks assigned to him. This study uses quantitative methods with data collection techniques through the distribution of questionnaires and interviews and then using multiple regression analysis tests to obtain answers to the hypothesis determined by the number of samples of 68 people. There are many factors that influence work discipline including compensation and leadership.
\end{abstract}

Keywords : Compensation, Leadership, Work Discipline

$\begin{array}{cc}\text { Info Artikel }: & \\ \text { Disubmit:11 November } 2021 & \text { Direview:20 Desember } 2021 \quad \text { Diterima :15 Januari } 2022\end{array}$

Copyright (C) 2022 - Journal Accumulated. All rights reserved.

\section{PENDAHULUAN}

\section{A. Latar Belakang}

Modal utama yang sangat penting untuk setiap pengawai dalam menjalankan tujuan perusahaan adalah dengan diterapkannya disiplin, dengan memiliki kedisiplinan yang baik kantor akan mudah melaksanakan program-program tujuan yang akan dicapainya karena semakin baik disiplin pengawai, maka semakin tinggi prestasi kerja yang akan dicapainya. 
Menurut Siagian (2010, hal 305) menyatakan disiplin pegawai adalah suatu bentuk pelatihan yang berusaha memperbaiki dan membentuk pengetahuan, sikap dan perilaku karyawan sehingga para pengawai tersebut secara sukarela berusaha bekerja secara koperatif dengan para pengawai yang lain serta meningkatkan prestasi kerjanya. Dalam hal ini disiplin yang baik akan mencerminkan sikap dan tanggung jawab seorang pengawai dalam menjalankan tugas-tugas yang diberikan padanya. Oleh sebab itu perlu di terapkannya peraturan disiplin dengan cara kantor harus membuat peraturan dan tata tertib yang tegas agar pengawai menaati peraturan tersebut. Ketegasan pimpinan dalam menegakkan peraturan perusahaan sanksi kepada pengawai yang melanggar peraturan jam kerja merupakan salah satu faktor yang dapat ditinjau dan sangat penting untuk kantor dalam usahanya meningkatkan dan membangun produktifitas pengawai. Dengan diberlakukannya sanksi yang tegas maka akan mencegah pelanggaran-pelanggaran yang dapat menghambat kelancaran kerja pengawai yang bersangkutan.

Ada banyak faktor-faktor yang mempengaruhi disiplin kerja salah satunya menurut Susilo (2007, hal 165) bahwa faktor-faktor yang mempengaruhi disiplin kerja pengawai antara lain motivasi, pendidikan, dan pelatihan, kepimimpina, penegakkan disiplin dan kompensasi. Menurut Siagian (2010, hal 305) menyatakan disiplin pegawai adalah suatu bentuk pelatihan yang berusaha memperbaiki dan membentuk pengetahuan, sikap dan perilaku karyawan sehingga para pengawai tersebut secara sukarela berusaha bekerja secara koperatif dengan para pengawai yang lain serta meningkatkan prestasi kerjanya. Dalam hal ini disiplin yang baik akan mencerminkan sikap dan tanggung jawab seorang pengawai dalam menjalankan tugas-tugas yang diberikan padanya. Setiap anggota dari suatu organisasi mempunyai kepentingan dan tujuan sendiri ketika ia bergabung pada organisasi tersebut. Bagi sebagian karyawan, harapan untuk mendapatkan uang adalah satu-satunya alasan untuk bekerja, namun yang lain berpendapat bahwa uang hanyalah salah satu dari banyak kebutuhan yang terpenuhi melalui kerja. Seseorang yang bekerja akan merasa lebih dihargai oleh masyarakat di sekitarnya, dibandingkan yang tidak bekerja. Untuk menjamin tercapainya keselarasan tujuan, pimpinan organisasi bisa memberikan perhatian dengan memberikan kompensasi, karena kompensasi merupakan bagian dari hubungan timbal balik antara organisasi dengan sumber daya manusia.

Menurut Handoko ( 2001:155) mengemukakan bahwa Kompensasi adalah "segala sesuatu yang diterima para karyawan sebagai balas jasa untuk kerja mereka." Kompensasi juga merupakan penghargaan yang diberikan karyawan baik langsung maupun tidak langsung, financial maupun non financial yang adil kepada karyawan atas kinerja mereka dalam mencapai tujuan organisasi, sehingga pemberian kompensasi sangat dibutuhkan oleh perusahaan manapun guna meningkatkan kinerja karyawannya. Adapun bentuk kompensasi financial adalah gaji, tunjangan, bonus (insentif),dan komisi. Sedangkan untuk kompensasi non-financial diantaranya pelatihan, wewenang dan tanggung jawab, penghargaan atas kinerja serta lingkungan kerja yang mendukung.

Pada Badan lingkungan hidup dan kebersihan Kabupaten Aceh Tenggara selama menjalankan prosedur kerjanya tentu tidak lepas dari berbagai masalah, salah satunya mengenai kedisiplinan kerja pengawai. Adapun data yang didapat oleh penulis pada Badan lingkungan hidup dan kebersihan Kabupaten Aceh Tenggara ternyata 30\% kedisiplinan kerja masih belum terdapat beberapa pengawai yang datang terlambat. Hal tersebut akan berdampak terhambatnya kelancaran kerja dimana pekerjaan yang seharusnya dapat diselesaikan tepat waktu malah menjadi tertunda dan target dari perencanaan yang telah disusun, tidak sesuai dengan target yang diharapkan.

\section{B. Tujuan Penelitian}

Adapun tujuan dari penelitian yang dilakukan ini adalah untuk mengetahui: 
1. Apakah ada pengaruh kompensasi terhadap disiplin kerja pada Badan lingkungaN hidup dan kebersihan Kabupaten Aceh Tenggara

2. Untuk mengetahui pengaruh kepemimpinan terhadap disiplin kerja pengawai pada Badan lingkungan hidup dan kebersihan Kabupaten Aceh Tenggara

\section{TINJAUAN PUSTAKA}

\section{A. Kompensasi}

Didalam pemberian kompensasi ini, hal-hal yang paling sulit dilakukan adalah bagaimana cara memberikan kompensasi yang layak dan adil bagi karyawan. Bila kompensasi yang diberikan perusahaan tersebut dirasakan tidak layak dan tidak adil, maka tujuan dari kompensasi itu sendiri kemungkinan besar tidak akan tercapai sesuai dengan apa yang diharapkan. Untuk mencapai tingkat keadilan dan kelayakan yang lebih baik, maka perbedaan pemberian kompensasi hanya berdasarkan kepada perbedaaan-perbedaan kegiatan manajerial, tanggung jawab, kemampuan, pengetahuan, dan produktifitas. Sastrohadiwiryo (2003 : 195) dalam jurnal Ririvega Kasenda (2013), kompensasi adalah balas jasa yang diberikan oleh perusahaan kepada tenaga kerja, karena tenaga kerja memberikan sumbangan tenaga dan pikiran demi kemajuan perusahaan guna mencapai tujuan yang ditetapkan dengan baik dalam jangka pendek maupun panjang. Lewa dan Subowo (2005) dalam jurnal Slamet Riyadi (2011), Kompensasi yang diberikan harus layak, adil, dapat diterimakan, memuaskan, memberi motivasi kerja, bersifat penghargaan dan sesuai dengan kebutuhan, pemberian kompensasi akan memberikan manfaat kepada kedua belah pihak, baik kepada pihak perusahaan maupun kepada pihak karyawan.

Hal ini didukung oleh beberapa penelitian (Omotayo et al. 2014, Alamdar et. al. 2012, Saani 2013, Ngui Thomas et al. 2014) dalam jurnal Domingos Belo Soares dan Gede Riana (2015), membuktikan bahwa paket kompensasi dengan kinerja karyawan memiliki hubungan yang sangat erat dan kompensasi berpengaruh signifian terhadap kinerja. Namun paket kompensasi harus dirancang khusu agar menarik kepuasan karyawan.

\section{B. Faktor-Faktor Kompensasi}

Faktor-faktor ini merupakan tantangan setiap perusahaan untuk menentukan kebijaksanaan kompensasi untuk karyawan. Faktor-faktor tersebut antara lain sebagal berikut Notoatmodjo (2009:144-145) dalam jurnal Sudarmin Manik (2016):

a. Produktivitas perusahaan apa pun berkeinginan untuk memperoleh keuntungan. Keuntungan ini dapat berupa material, maupun keuntungan non material. Untuk itu perusahaan harus mempertimbangkan produktivitas karyawannya dalam kontribusinya terhadap keuntungan perusahaan.

b. Kemampuan untuk membayar pemberian kompensasi akan tergantung kepada kemampuan perusahaan itu untuk membayar (ability to pay).

c. Kesediaan untuk membayar kesedian untuk membayar akan (willingness to pay) akan berpengaruh terhadap kebijaksanaan pemberian kompensasi kepada karyawannya.

d. Permintaan tenaga kerja banyak sedikitnya tenaga kerja di pasaran kerja akan mempegaruhi sistem pemberian kompensasi.

e. Organisasi karyawan dengan adanya organisasi-organisasi karyawan akan mempengaruhi kebijakan pemberian kompensasi.

f. Berbagai peraturan dan perundang-undangan dengan semakin baik sistem pemerintahan, maka makin baik pula sistem perundangundangan termasuk di bidang perburuhan (karyawan) atau ketenagakerjaan. 


\section{Kepemimpinan}

Menurut Dewi Lina (2014), kepemimpinan yang efektif harus memberikan pengarahan terhadap usaha-usaha semua pekerja dalam mencapai tujuan organisasi. Tanpa kepemimpinan, hubungan antara tujuan perseorangan dan tujuan organisasi mungkin menjadi tidak searah. Keadaan ini menimbulkan situasi dimana perseorangan bekerja untuk mencapai tujuan pribadinya, Sementara itu keseluruhan organisasi menjadi tidak efisien dalam pencapaian sasaran-sasarannya. Kepemimpinan merupakan suatu kemampuan yang melekat pada diri seorang yang memimpin yang tergantung dari macam-macam faktor baik faktor-faktor intern maupun faktor-faktor ekstern.

Terry dalam (Kartono, 2006) jurnal Tri Yuliani dan Muhammad Kritiawan (2016) mendefinisikan kepemimpinan adalah aktivitas mempengaruhi orang-orang untuk mencapai tujuan kelompok. Dalam usaha mencapai tujuan tersebut perlu seorang pemimpin untuk melakukan supervisi untuk menjaga apakah langkah-langkah yang diambil telah sesuai dengan peraturan yang telah ditetapkan. Dimana Terry mengungkapkan bahwa supervisi adalah usaha mencapai hasil yang diinginkan dengan cara mendayagunakan bakat atau kemampuan alami manusia dan sumbersumber yang memfasilitasi, yang ditekankan pada pemberian tantangan dan perhatian yang sebesar-besarnya terhadap bakat atau kemampuan alami manusia.

\section{Indikator Kepemimpinan}

Indikator kepemimpinan menurut Martoyo (2000: 176-179) dalam Deltia (2015) yaitu :

1. Kemampuan Analitis Kemampuan menganalisa situasi yang dihadapi secara teliti, matang dan mantap merupakan prasyarat untuk suksesnya kepemimpinan seseorang.

2. Keterampilan Berkomunikasi Dalam memberikan perintah, petunjuk, pedoman, nasihat, seorang pemimpin harus menguasai tehnik-tehnik berkomunikasi.

3. Keberanian.

Semakin tinggi kedudukan seseorang dalam organisasi ia perlu memiliki keberanian yang semakin besar dalam melaksakan tugas pokoknya yang telah dipercayakan padanya.

4. Kemampuan Mendengar

Salah satu sifat yang perlu dimiliki oleh setiap pemimpin adalah kemampuannya serta kemauannya mendengar pendapat dan atau saran-saran orang lain, terutama bawahannya.

5. Ketegasan

Ketegasan dalam menghadapi bawahan dan menghadapi ketidaktentuan, sangat penting bagi seorang pemimpin.

\section{METODE}

\section{A. Sumber Data}

Populasi dalam penelitian ini adalah seluruh karyawan tetap di Badan lingkungan hidup dan kebersihan Kabupaten Aceh Tenggara.

Dalam menetukan hasil penelitian, penelitian ini menggunakan teknik Probability Sampling, dengan bentuk sampling jenuh (sensus) dengan populasi homogeny. Dengan persamaan Probability Sampling sebagai berikut: 


$$
n=\frac{N}{1+N e^{2}}
$$

Dari persamaan itu didapat sample sebesar 68 orang.

\section{B. Analisis Data}

Analisis data yang dilakukan pada penelitian ini yaitu menggunakan metode kuantitatif dengan menggunakan metode survey. Motode survey adalah metode yang digunakan untuk mendapatkan data dari tempat tertentu, dimana peneliti melakukan perlakuan dalam pengumpulan data, misalnya dengan mengedarkan kuesioner, tes, wawancara terstruktur, dan sebagainya (Sugiyono, 2014). Pendekatan kuantitatif digunakan karena data yang akan digunakan untuk menganalisis pengaruh antar variabel dinyatakan dengan angka.Setelah melakukan pengumpulan data, dengan cara sebagai memberikan quisioner,interview,studi dokumentasi, selanjutnya digunakan uji validitas dan realibilitas untuk menguji keakuratan korelasi pertanyaan dan angket yang digunakan, kemudian analisi data untuk menjawab hipotesis yang ditentukan menggunakan regresi linier berganda.

1. Angket (Quistioner)

Quistioner merupakan teknik pengumpulan data yang dilakukan dengan cara member seperangakat pertanyaan atau pernyataan tertulis kepada responden untuk dijawabnya Sugiyono (2010,hal.199).

Teknik pengumpulan data dengan membuat daftar pertanyaan dalam bentuk angket yang ditujukan kepada karyawan di objek penelitian yaitu Badan lingkungan hidup dan kebersihan Kabupaten Aceh Tenggara dengan menggunakan skala Likert dengan bentuk checklist, dimana setiap pertanyaan mempunyai 5 opsi.

\begin{tabular}{|l|c|}
\hline \multicolumn{1}{|c|}{ PERNYATAAN } & BOBOT \\
\hline 1. Sangat Setuju & 5 \\
\hline 2. Setuju & 4 \\
\hline 3. Kurang Seteju & 3 \\
\hline 4. Tidak Setuju & 2 \\
\hline 5. Sangat Tidak Setuju & 1 \\
\hline
\end{tabular}

Jumlah opsi jawaban dalam penelitian ini ada 5 yaitu : Sangat setuju, setuju, kurang setuju, tidak setuju, sangat tidak setuju.

2. Interview (Wawancara)

Merupakan usaha mengumpulkan informasi dengan mengajukan sejumlah pertanyaan secara lisan,untuk dijawab secara lisan pula. Dalam wawancara ini dilakukan dengan pertanyaan secara tertentu.

3. Studi Dokumentasi

Mengumpulkan data-data yang ada dalam perusahaan yang berhubungan dengan penelitiaan ini seperti sejarah kantor, kegiatan operasional kantor, visi dan misi, struktur organisasi kantor, serta deskripsi tugas kantor/job descriptions.

a) Uji Validitas Dan Realibitas

Validitas berkenaan dengan tingkat kecermatan suatu instrument penelitian. Untuk mengukur validitas setiap pertanyaan,maka digunakan teknik korelasi product moment (Sugiyono, 2012, hal.248) Yaitu: 


$$
r x y=\frac{\mathrm{n} \sum x_{i} y_{i}-\left(\sum x_{i}\right)\left(\sum y_{i}\right)}{\sqrt{\left\{n \sum x_{i}^{2}-\left(\sum x_{i}\right)\right\}\left\{n \sum y_{i}^{2}-\left(\sum y_{i}\right)\right\}}}
$$

b) Uji Reliabilitas

Pengujian reliabilitas digunakan untuk menguji apakah angket yang digunakan adalah alat ukur yang bisa dipercaya atau tidak.Untuk menguji reliabilitas dilakukan dengan menggunakan rumus Cronbach Alpha sebagai berikut:

$$
r=\left[\frac{k}{k-l}\right]\left[\frac{\sum \sigma b^{2}}{\sigma i^{2}}\right]
$$

\section{c) Analisa Data Regresi Linier Berganda}

Teknik analisis data yang digunakan dalam penelitian ini adalah kuantitatif, yakni menguji dan menganalisis data dengan perhitungan angka-angka dan kemudian menarik kesimpulan dari pengujian tersebut,statistik yang digunakan adalah sebagai berikut:

i. Uji Asumsi Klasik

Agar regresi berganda dapat digunakan, maka terdapat kriteria-kriteria dalam asumsi klasik,yakni:

ii. Uji Normalitas

Pengujian normalitas data dilkukan untuk melihat apakah dalam model regresi, variable devendent dan independennya memiliki distribusi normal atau tidak (Juliandi dan Irfan, 2013, hal. 168). Untuk mendekati normalitas data dapat diuji dengan kolmogov-smirnov yang bertujuan untuk menguji apakah dalam model regresi, varible penggangu atau residual memiliki distribusi normal.

iii. Uji Heterokedastisitas

Bertujuan untuk menguju apakah dalam medel regresi terjadi ketidaksamaan variance dari residual dari suatau pengamatan yang lain.Jika variasi residual dari satu pengamatan ke pengamatan yang lain tetap,maka disebut homokedastisitas, dan jika varians berbeda disebut heterokedasititas. Model yang baik adalah tidak terjadi heterokedastisitas.(Juliandi dan Irfan, 2013, hal.168)

iv. Uji Autokorelasi

Autokorelasi bertujuan untuk menguji apakah dalam sebuah model regresi linier adalah korelasi antara kesalahan pengganggu pada priode ke $t$ dengan kesalahan dengan periode t-1 (sebelumnya).Jika terjadi kolerasi, maka dinamakan ada problem autokolerasi.Model regresi yang baik adalah bebas dari autokolersi.(Juliandi dan Irfan:2013,hal.173)

\section{d) Regresi Berganda}

Analisis regresi bertujuan untuk memprediksi perubahan nilai variable terikat akibat pengaruh dari nilai variable bebas.

(Sugiyono, 2012, hal. 227)

$$
\mathrm{Y}=\mathrm{a}-\mathrm{b}_{1} \mathrm{X}_{1}+\mathrm{b}_{2} \mathrm{X}_{2}
$$

e) Uji-t (persial)

Untuk mengetahui signifikan atau tidaknya pengaruh masing-masing variable motivasi, variable pendidikan dan pelatihan, variable kepemimpinan dan variable kompensasi terhadap variable disiplin kerja digunakan uji $t$ dengan rumus:

$$
\mathrm{t}=\frac{\mathrm{r} \sqrt{r-2}}{\sqrt{1-r^{2}}}
$$


f) Uji F

Uji $F$ atau disebut juga dengan uji signifikan serentak dimaksud untuk melihat kemampuan menyeluruh dari variable bebas yaitu $X_{1}$ dan $X_{2}$ untuk dapat atau mampu menjelaskan tingkah laku atau keragaman variable tidak bebas $\mathrm{Y}$ Uji $\mathrm{F}$ juga dimaksuskan untuk mengetahui apakah semua variable memiliki koefissien regresi sama dengan nol. Nilai F hitung ditentukan dengan rumus sebagai berikut :

$$
\mathrm{Fh}=\frac{R^{2}}{\left(1-R^{2}\right) /(n-k-l)}
$$

(Sugiyono, 2012,hal. 257)

\section{g) Koefisien Determinasi}

Untuk mengetahui apakah ada pengaruh antara variable bebas dengan variable terikat digunakan koefien determinasi, yaitu dengan mengkuadratkan koefisien yang ditemukan, yaitu dengan menggunakan rumus sebagai berikut:

$\mathrm{D}=R^{2} \times 100 \%$

(Sugiyono, 2012 )

\section{HASIL DAN PEMBAHASAN}

\section{A. Hasil Penelitian}

\section{a. Data Des kriptif}

Dalam penelitian ini penulis mengolah angket dalam bentuk data yang terdiri dari 15 pernyataan untuk variable kompensasi ( $\left.\mathrm{X}_{1}\right)$,kepemimpinan $(\mathrm{X} 2)$ dan disiplin kerja $(\mathrm{Y})$. Angket yang disebarkan ini diberikan kepada 68 orang pegawai Badan Lingkungan Hidup dan Kebersihan Kabupaten Aceh Tenggara sebagai sampel penelitian dan dengan menggunakan metode Likert Summated Rating (LSR). Karakteristik responden yang ada di Badan Lingkungan Hidup dan Kebersihan Kabupaten Aceh Tenggara untuk tahun 2015.

\section{Dis tribusi Responden Berdasarkan Usia}

\begin{tabular}{|l|l|l|l|}
\hline No & $\begin{array}{l}\text { Usia } \\
\text { Responden }\end{array}$ & Jumlah & Persentase \\
\hline 1 & $21-30$ & 6 orang & $9 \%$ \\
\hline 2 & $30-40$ & 24 orang & $35 \%$ \\
\hline 3 & $41-50$ & 29 orang & $43 \%$ \\
\hline 4 & $51-60$ & 9 orang & $13 \%$ \\
\hline Jumlah & 68 orang & $100 \%$ \\
\hline
\end{tabular}

Dari tabel diketahui bahwa responden yang bekerja pada kelompok umur 21-30 tahun sebanyak 6 orang (9\%), 31-40 tahun sebanyak 24 orang (35\%),41-50 tahun sebanyak 29 orang (43\%),51-60 tahun sebanyak 9 orang (13\%).

\section{Distribusi Responden Berdasarkan Jenis Kelamin}

\begin{tabular}{|l|l|l|l|}
\hline No & Jenis Kelamin & Jumlah & Persentase \\
\hline 1 & Laki-Laki & 50 & $74 \%$ \\
\hline 2 & Perempuan & 18 & $26 \%$ \\
\hline \multicolumn{2}{|l|}{ Jumlah } & 68 & $100 \%$ \\
\hline
\end{tabular}


Dari tabel dapat diketahui bahwa responden yang bekerja terdiri dari 50 orang lakilaki $(74 \%)$ dan perempuan sebanyak 18 orang $(26 \%)$ dari total keseluruhan.

\section{Skor Angket untuk Variabel Kompensasi}

\begin{tabular}{|c|c|c|c|c|c|c|c|c|c|c|c|c|}
\hline \multicolumn{13}{|c|}{ Alternatif Jawaban } \\
\hline \multirow[t]{2}{*}{ No } & \multicolumn{2}{|l|}{ SS } & \multicolumn{2}{|l|}{$S$} & \multicolumn{2}{|c|}{$\begin{array}{l}\text { KS } \\
\end{array}$} & \multicolumn{2}{|c|}{$\mathrm{TS}$} & \multicolumn{2}{|c|}{ STS } & \multicolumn{2}{|c|}{ Jumlah } \\
\hline & $\mathrm{F}$ & $\%$ & $\mathrm{~F}$ & $\%$ & $\mathrm{~F}$ & $\%$ & $\mathrm{~F}$ & $\%$ & $\mathrm{~F}$ & $\%$ & $\mathrm{~F}$ & $\%$ \\
\hline 1 & 20 & 29 & 44 & 65 & 4 & 6 & 0 & 0 & 0 & 0 & 68 & 100 \\
\hline 2 & 19 & 28 & 32 & 47 & 17 & 25 & 0 & 0 & 0 & 0 & 68 & 100 \\
\hline 3 & 25 & 37 & 25 & 37 & 18 & 26 & 0 & 0 & 0 & 0 & 68 & 100 \\
\hline 4 & 25 & 37 & 39 & 57 & 4 & 6 & 0 & 0 & 0 & 0 & 68 & 100 \\
\hline 5 & 22 & 32 & 42 & 62 & 4 & 6 & 0 & 0 & 0 & 0 & 68 & 100 \\
\hline 6 & 19 & 18 & 32 & 47 & 17 & 25 & 0 & 0 & 0 & 0 & 68 & 100 \\
\hline
\end{tabular}

Dari tabel sebelumnya dapat diuraikan sebagai berikut:

1. Jawaban responden tentang hasil yang diberikan pada pengawai telah mampu memenuhi kebutuhan sehari-hari pengawai adalah 44 orang atau $65 \%$ menyatakan setuju.

2. Jawaban responden tentang pemberian sesuai dengan kemampuan dan penempatan kerja adalah 32 orang atau $47 \%$ menyatakan setuju.

3. Jawaban responden tentang motivasi dan semangat kerja terpicu dengan tunjangan yang diterima adalah 25 orang atau $37 \%$ menyatakan setuju.

4. Jawaban responden tentang kantor memberikan kompensasi berupa intensif kerja kepada pengawai yang berprestasi adalah 39 orang atau 57\% menyatakan setuju.

5. Jawaban responden tentang dalam mengontrol pembayaran kantor tidak membedabedakan adalah 42 orang atau $62 \%$ menyatakan setuju.

6. Jawaban responden tentang pembayaran tepat waktu adalah 32 orang atau $47 \%$ menyatakan setuju.

Skor Angket untuk Variabel Kepemimpinan

\begin{tabular}{|c|c|c|c|c|c|c|c|c|c|c|c|c|}
\hline \multicolumn{13}{|c|}{ Alternatif Jawaban } \\
\hline \multirow[t]{2}{*}{ No } & \multicolumn{2}{|c|}{ SS } & \multicolumn{2}{|l|}{$\bar{S}$} & \multicolumn{2}{|c|}{ KS } & \multicolumn{2}{|c|}{ TS } & \multicolumn{2}{|c|}{ STS } & \multicolumn{2}{|c|}{ Jumlah } \\
\hline & $\bar{F}$ & $\%$ & $\bar{F}$ & $\%$ & $\bar{F}$ & $\%$ & $\overline{\mathrm{F}}$ & $\%$ & $\bar{F}$ & $\%$ & $\bar{F}$ & $\%$ \\
\hline 1 & 22 & 32 & 34 & 50 & 12 & 18 & 0 & 0 & 0 & 0 & 68 & 100 \\
\hline 2 & 26 & 38 & 39 & 57 & 3 & 4 & 0 & 0 & 0 & 0 & 68 & 100 \\
\hline 3 & 22 & 32 & 39 & 57 & 5 & 7 & 2 & 3 & 0 & 0 & 68 & 100 \\
\hline 4 & 19 & 28 & 36 & 53 & 13 & 19 & 0 & 0 & 0 & 0 & 68 & 100 \\
\hline 5 & 21 & 31 & 36 & 53 & 10 & 15 & 1 & 1 & 0 & 0 & 68 & 100 \\
\hline 6 & 31 & 46 & 30 & 44 & 7 & 10 & 0 & 0 & 0 & 0 & 68 & 100 \\
\hline 7 & 25 & 37 & 31 & 46 & 12 & 18 & 0 & 0 & 0 & 0 & 68 & 100 \\
\hline 8 & 23 & 34 & 37 & 54 & 8 & 12 & 0 & 0 & 0 & 0 & 68 & 100 \\
\hline 9 & 20 & 29 & 41 & 60 & 7 & 10 & 0 & $\overline{0}$ & $\overline{0}$ & 0 & 68 & 100 \\
\hline 10 & 26 & 38 & 34 & 50 & 7 & 10 & 1 & 1 & 0 & $\overline{0}$ & 68 & 100 \\
\hline 11 & 12 & 18 & 30 & 44 & 25 & 37 & 1 & 1 & 0 & 0 & 68 & 100 \\
\hline 12 & 28 & 41 & 33 & 49 & 7 & 10 & 0 & 0 & 0 & 0 & 68 & 100 \\
\hline 13 & 17 & 25 & 43 & 63 & 7 & 10 & 1 & 1 & $\overline{0}$ & $\overline{0}$ & 68 & 100 \\
\hline 14 & 12 & 18 & 27 & 40 & 27 & 40 & 2 & 3 & 0 & 0 & 68 & 100 \\
\hline 15 & 17 & 25 & 35 & 51 & 16 & 24 & 0 & 0 & 0 & 0 & 68 & 100 \\
\hline
\end{tabular}

Dari tabel sebelumnya dapat diuraikan sebagai berikut: 
1. Jawaban responden tentang mampu memberikan pengarahan yang baik adalah 34 orang atau $50 \%$ menyatakan setuju.

2. Jawaban responden tentang bekerja sigap dalam mengawasi pengawai adalah 39 orang atau $57 \%$ menyatakan setuju.

3. Jawaban responden tentang menerima setiap saran atau masukan dari pengawai tetapi keputusan sepenuhnya ditentukan pemimpin adalah 39 orang atau 57\% menyatakan setuju.

4. Jawaban responden tentang selalu memotivasi pengawai agar mau melakukan yang terbaik adalah 36 orang atau $53 \%$ menyatakan setuju.

5. Jawaban responden tentang mendiskusikan dengan kebijaksanaan penyelesaian pelaksanaan yang terjadi guna mencari solusinya bila ada penurunan kinerja pengawai adalah 36 orang atau 53\% menyatakan setuju.

6. Jawaban responden tentang pemimpin yang mampu berinteraksi baik didalam maupun diluar kantor adalah 30 orang atau $44 \%$ menyatakan setuju.

7. Jawaban responden tentang pemimpin selalu dapat memberikan solusi yang tepat adalah 31 orang atau $46 \%$ menyatakan setuju.

8. Jawaban responden tentang pemimpin memiliki wawasan yang luas adalah 37 orang atau $54 \%$ menyatakan setuju.

9. Jawaban responden tentang bertindak secara adil 41 orang atau $60 \%$ menyatakan setuju.

10. jawaban responden tentang tidak pernah ragu-ragu dalam mengambil keputusan adalah 34 orang atau $50 \%$ menyataka setuju.

11. Jawaban responden tentang pemimpin akan memberikan sanksi kepada pengawai yang melakukan kesalahan adalah 30 orang atau $44 \%$ menyatakan setuju.

12. Jawaban responden tentang pemimpin membuat peraturan yang tegas adalah 33 orang atau $49 \%$ menyatakan setuju.

13. Jawaban responden tentang mengembangkan dan memberdayakan kreatifitas daya pikir manusia adalah 43 orang atau $63 \%$ menyatakan setuju.

14. Jawaban responden tentang memanfaatkan setiap peluang disetiap pergantian waktu adalah 27 orang atau $40 \%$ menyatakan setuju.

15. Jawaban responden tentang mengambil keputusan tanpa bermusyawarah kepada pengawai adalah 35 orang atau $51 \%$ menyatakan setuju.

Skor Angket untuk Variabel Disiplin Kerja

\begin{tabular}{|c|c|c|c|c|c|c|c|c|c|c|c|c|}
\hline \multicolumn{13}{|c|}{ Alternatif Jawaban } \\
\hline \multirow[t]{2}{*}{ No } & \multicolumn{2}{|l|}{ SS } & \multicolumn{2}{|l|}{$\mathrm{S}$} & \multicolumn{2}{|c|}{$\mathrm{KS}$} & \multicolumn{2}{|c|}{$\mathrm{TS}$} & \multicolumn{2}{|c|}{ STS } & \multicolumn{2}{|c|}{ Jumlah } \\
\hline & $\mathrm{F}$ & $\%$ & $\mathrm{~F}$ & $\%$ & $\mathrm{~F}$ & $\%$ & $\mathrm{~F}$ & $\%$ & $\mathrm{~F}$ & $\%$ & $\mathrm{~F}$ & $\%$ \\
\hline 1 & 20 & 29 & 40 & 59 & 6 & 9 & 2 & 3 & 0 & 0 & 68 & 100 \\
\hline 2 & 17 & 25 & 37 & 54 & 14 & 21 & 0 & 0 & 0 & 0 & 68 & 100 \\
\hline 3 & 21 & 31 & 36 & 53 & 10 & 15 & 1 & 1 & 0 & 0 & 68 & 100 \\
\hline 4 & 30 & 44 & 30 & 44 & 8 & 12 & 0 & 0 & 0 & 0 & 68 & 100 \\
\hline 5 & 24 & 35 & 31 & 46 & 13 & 19 & 0 & 0 & 0 & 0 & 68 & 100 \\
\hline 6 & 21 & 31 & 38 & 56 & 9 & 13 & 0 & 0 & 0 & 0 & 68 & 100 \\
\hline 7 & 20 & 29 & 40 & 59 & 8 & 12 & 0 & 0 & 0 & 0 & 68 & 100 \\
\hline 8 & 27 & 40 & 33 & $\overline{49}$ & 7 & 10 & 1 & 1 & 0 & 0 & 68 & 100 \\
\hline
\end{tabular}

Dari tabel sebelumnya dapat diuraikan sebagai berikut:

1. Jawaban responden masuk kerja tepat waktu dari jadwal yang ditentukan adalah 40 orang tau $59 \%$ menyatakan setuju.

2. Jawaban responden tentang mengikuti segala kegiatan yang dibuat perusahaan adalah 37 orang atau $54 \%$ menyatakan setuju.

3. Jawaban responden tentang berada diruangan kantor pada waktu jam kerja adalah 36 orang atau 53\% menyatakan setuju. 
4. Jawaban responden tentang memakai seragam kerja yang sudah di tetapkan oleh kantor adalah 30 orang atau $44 \%$ menyatakan setuju.

5. Jawaban responden tentang bertanggung jawab dengan pekerjaan yang diberikan adalah 31 orang atau $46 \%$ menyatakan setuju.

6. jawaban responden tentang mematuhi peraturan bekerja yang sudah ditentukan kantor adalah 38 atau $56 \%$ menyatakan setuju.

7. Jawaban responden mengkoreksi kembali hasil kerja yang sudah dikerjakan adalah 40 orang atau $59 \%$ menyatakan setuju.

8. Jawaban responden tentang bekerja lebih baik lagi dari apa yang sudah didapatkan adalah 33 orang atau $49 \%$ menyatakan setuju.

b. Pengujian Validitas dan Re liabilitas

Hasil Uji Validitas Variabel Kompensasi

\begin{tabular}{|l|l|l|l|}
\hline No & r hitung & r tabel & status \\
\hline 1 & 0,683 & 0,239 & Valid \\
\hline 2 & 0,887 & 0,239 & Valid \\
\hline 3 & 0,818 & 0,239 & Valid \\
\hline 4 & 0,657 & 0,239 & Valid \\
\hline 5 & 0,719 & 0,239 & Valid \\
\hline 6 & 0,847 & 0,239 & Valid \\
\hline
\end{tabular}

Keseluruhan butir pertanyaan untuk variabel kompensasi (X4) dalam kategori valid.

Hasil Uji Validitas Variabel Kepemimpinan

\begin{tabular}{|l|l|l|l|}
\hline No & r hitung & r tabel & status \\
\hline 1 & 0,805 & 0,239 & Valid \\
\hline 2 & 0,553 & 0,239 & Valid \\
\hline 3 & 0,494 & 0,239 & Valid \\
\hline 4 & 0,832 & 0,239 & Valid \\
\hline 5 & 0,636 & 0,239 & Valid \\
\hline 6 & 0,730 & 0,239 & Valid \\
\hline 7 & 0,793 & 0,239 & Valid \\
\hline 8 & 0,775 & 0,239 & Valid \\
\hline 9 & 0,661 & 0,239 & Valid \\
\hline 10 & 0,544 & 0,239 & Valid \\
\hline 11 & 0,694 & 0,239 & Valid \\
\hline 12 & 0,668 & 0,239 & Valid \\
\hline 13 & 0,444 & 0,239 & Valid \\
\hline 14 & 0,728 & 0,239 & Valid \\
\hline 15 & 0,822 & 0,239 & Valid \\
\hline
\end{tabular}

Keseluruhan butir pertanyaan untuk variabel kepemimpinan (X3) dalam kategori valid.

Hasil Uji Validitas Variabel Disiplin Kerja

\begin{tabular}{|l|l|l|l|}
\hline No & r hitung & r tabel & status \\
\hline 1 & 0,506 & 0,239 & Valid \\
\hline 2 & 0,838 & 0,239 & Valid \\
\hline 3 & 0,761 & 0,239 & Valid \\
\hline 4 & 0,788 & 0,239 & Valid \\
\hline 5 & 0,756 & 0,239 & Valid \\
\hline 6 & 0,773 & 0,239 & Valid \\
\hline 7 & 0,772 & 0,239 & Valid \\
\hline 8 & 0,689 & 0,239 & Valid \\
\hline
\end{tabular}


Keseluruhan butir pertanyaan untuk variabel disiplin kerja (Y) dalam kategori valid

\section{Hasil Uji Reliabilitas}

\begin{tabular}{|l|l|l|l|}
\hline Variabel & Cronbach Alpha & r tabel & Status \\
\hline Kepemimpinan & 0,917 & 0,6 & Reliabel \\
\hline Kompensasi & 0,864 & 0,6 & Reliabel \\
\hline Disipilin Kerja & 0,877 & 0,6 & Reliabel \\
\hline
\end{tabular}

Dari tabel IV-14 maka dapat diketahui bahwa realibilitas variabel kepemimpian $\left(\mathrm{X}_{3}\right)$ sebesar 0,917, variabel kompensasi $\left(\mathrm{X}_{4}\right)$ sebesar 0,864 dan variabel disiplin kerja $(\mathrm{Y})$ sebesar 0,877 .

\section{c. Analisis Regresi Linear Berganda}

Sebelum menggunakan regresi berganda maka dilakukan syarat uji berupa Uji Asumsi Klasik dimana terdiri dari uji normalitas, uji heterokedastisitas, uji multikoleniaritas, uji autokolerasi dengan hasil sebagai berikut:

Hasil uji normalitas : Pengujian normalitas data dilakukan untuk melihat apakah dalam model regresi, variabel devident dan independennya memiliki distribusi normal atau tidak (Juliandi dan Irfan,2013,hal.168). Untuk mendekati normalitas data dapat diuji dengan kolmogov-smirnov yang bertujuan untuk menguji apakah dalam model regresi, variabel penggangu atau residual memiliki distribusi normal.Dapat diketahui bahwa nilai Asymp.Sig (2-tailed) pada motivasi (0,643),pendidikan dan pelatihan (0,614),Kepemimpinan $(0,821)$,kompensasi $(0,148)$ dan disiplin kerja $(0,387)$.Dimana nilai masing-masing tersebut memiliki nilai yang lebih besar dari tingkat signifikan yaitu 0,05.maka dapat disimpulkan bahwa model regresi dalam penelitian ini memenuhi asumsi normalitas atau telah terdistribusi normal dan layak untuk diteliti.

Hasil uji heterokedastisitas: Bertujuan untuk menguji apakah dalam model regresi terjadi ketidaksamaan variance dari residual dari suatu pengamatan yang lain. jiak variasi residual dari satu pengamatan ke pengamatan yang lain tetap,maka disebut homokedastisitas,dan jika varians berbeda disebut heterokedasititas.Modal yang baik adalah tidak terjadi heterokedastisitas.(Juliandi dan Irfan,2013,hal.168). Hasil pengujian heterokedastisitas pada penelitian dapat dilihat berdasarkan gambar berikut:

\section{Uji Heteroskedastisitas}

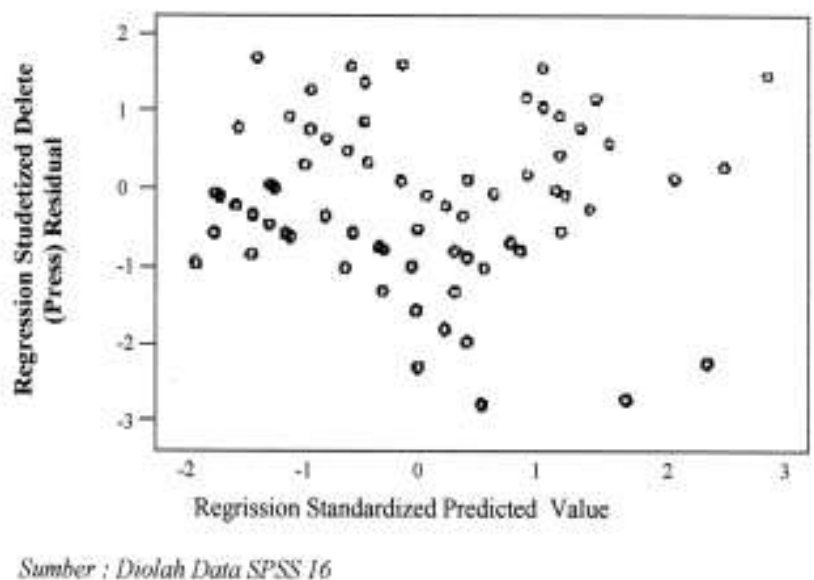

Gambar di atas memperlihatkan titik-titik menyebar secara acak, tidak membentuk pola yang jelas/teratur, serta tersebar baik diatas maupun di bawah angka 0 pada sumbu Y. dengan 
demikian "Tidak terjadi heterokedastisitas" pada model regresi. Berdasarkan gambar di atas terlihat bahwa titik-titik menyebar secara acak serta tersebar baik diatas maupun dibawah angka 0 pada sumbu Y. Hal ini disimpulkan bahwa tidak terjadi heterokedastisitas pada model regresi.

Hasil Uji Autokole rasi

\begin{tabular}{|c|c|c|c|l|c|}
\hline Model & $\mathrm{R}$ & $\begin{array}{l}\mathrm{R} \\
\text { Square }\end{array}$ & $\begin{array}{l}\text { Adjusted } \\
\mathrm{R} \\
\text { Square }\end{array}$ & $\begin{array}{l}\text { Std. } \\
\text { Error Of } \\
\text { The } \\
\text { Estimate }\end{array}$ & $\begin{array}{l}\text { Durbin- } \\
\text { Watson }\end{array}$ \\
\hline 1 & $.966^{\mathrm{a}}$ & .933 & .929 & 1,06707 & 1.885 \\
\hline
\end{tabular}

a. Predictors: (Constant), Kompensasi, Kepemimpinan, Motivasi, Pendidikan, Pelatihan

b. Dependent Variable:Disiplin Kerja

Uji autokorelasi dimaksudkan untuk mengetahui apakah terjadi korelasi antara anggota serangkaian data observasi yang diuraikan menurut waktu ( time series ) atau cross sectional.hal ini mempunyai arti bahwa satu tahun tertentu dipengaruhi oleh tahun berikutnya.untuk menguji ada tidaknya autokorelasi ini dapat dilakukan dengan menggunakan Watson Statistik, yaitu dengan melihat koefesien korelasi Durbin Watson.Cara mengetahui autokorelasi yaitu dengan melihat nilai Durbin Watson (D-W):

1) Jika nilai D-W dibawah-2,maka ada autokorelasi positif

2) Jika nilai D-W diantara -2 sampai +2 , maka tidak ada autokorelasi.

3) Jika nilai D-W diatas -2, maka autokorelasi negative.

Adapun data hasil uji autokorelasi dalam penelitian ini dapat dilihat pada tabel berikut: Berdasarkan tabel diatas dapat dilihat diperoleh nilai Durbin Watson (DW) yaitu sebesar 1.855 yang berarti $1.855<2$ hal ini akan dapat disimpulkan bahwa dari angka DurbinWatson tersebut tidak terjadi autokorelasi.

\section{d. Analisa Regresi Berganda}

Analisis regresi digunakan untuk mengetahui pengaruh dari variabel bebas terhadap variabel terikat. Persamaan regresi dalam penelitian ini adalah sebagai berikut:

Secara umum, analisis regresi pada dasarnya adalah suatu studi mengenai ketergantungan variabel independen denagn satu atau lebih variabel independen,dengan tujuan untuk mengestimasi dan atau memprediksi rata-rata populasi atau nilai rata-rata varibel dependen berdasar nilai variabel independen yang diketahui.

\begin{tabular}{|l|l|l|l|}
\hline \multirow{2}{*}{ Model } & \multicolumn{2}{|l|}{$\begin{array}{l}\text { Unstandardized } \\
\text { Coefficients }\end{array}$} & $\begin{array}{l}\text { Standardized } \\
\text { Coefficients }\end{array}$ \\
\cline { 2 - 4 } & $\mathrm{B}$ & Std. Error & Beta \\
\hline 1 (Constants) & 2,596 & 1,482 & \\
Kepemimpinan &,- 026 &, 118 &,- 045 \\
Kompensasi &,- 108 &, 059 &,- 083 \\
\hline
\end{tabular}

Berdasarkan tabel diatas, maka persamaan regresi linier berganda yang dapat diformulasikan adalah sebagai berikut: 
a) Koefisien regresi kepemimpinan $\left(X_{3}\right)$ sebesar $-0,026$ menjelaskan bahwa setiap peningkatan pendidikan dan pelatihan $\left(\mathrm{X}_{3}\right)$ setiap 1 poin, sementara yang lain konstan maka akan berpengaruh secara signifikan terhadap disiplin kerja pengawai pada Badan Lingkungan Hidup dan Kebersihan Kabupaten Aceh Tenggara.

b) Koefesien regresi kompensasi $\left(\mathrm{X}_{4}\right)$ sebesar $-0,108$ menjelaskan bahwa setiap peningkatan Kompensasi $\left(\mathrm{X}_{4}\right)$ sebesar 1 poin, sementara yang lain konstan maka akan berpengaruh secara signifikan terhadap disiplin kerja pengawai pada Badan Lingkungan Hidup dan Kebersihan Kabupaten Aceh Tenggara.

\section{e. Uji T (Parsial)}

Uji statistic $\mathrm{t}$ dilakukan untuk menguji apakah variabel bebas $(\mathrm{X})$ secara persial mempunyai hubungan yang signifikan atau tidak terhadap variabel terikat (Y).Untuk menguji signifikan hubungan, digunakan rumus uji statistic t sebagai berikut:

$$
\mathrm{t}=\mathrm{r} \sqrt{\frac{n-2}{1-r^{2}}}
$$

Dimana:

$\mathrm{t}=$ nilai $\mathrm{t}$ hitung

$\mathrm{r}=$ koefisien korelasi

$\mathrm{n}=$ banyaknya pasangan rank

Adapun data hasil pengujian yang diperoleh dari SPSS 16 dapat dilihat berdasarkan tabel dibawah ini:

\begin{tabular}{|l|l|l|l|l|l|}
\hline \multirow{2}{*}{ Model } & \multicolumn{2}{|l|}{$\begin{array}{l}\text { Unstandardized } \\
\text { Coeffecients }\end{array}$} & $\begin{array}{l}\text { Standardized } \\
\text { Coeffecients }\end{array}$ & & \\
\cline { 2 - 6 } & $\mathrm{B}$ & Std.Error & Sing. & T & Beta \\
\hline 1 ( Constants) & 2,596 & 1,482 &, 852 & 1,751 & \\
Kepemimpinan &,- 026 &, 118 &, 827 &,- 219 &,- 045 \\
Kompensasi &,- 108 &, 059 & 0,69 & $-1,849$ &,- 083 \\
\hline
\end{tabular}

Berdasarkan tabel diatas, maka dapat diketahui nilai perolehan uji $\mathrm{t}$ untuk pengaruh anatara kepemimpinan dan kompensasi terhadap disiplin kerja. Uji t digunakan untuk mengetahui apakah kepemimpinan secara individual mempunyai hubungan yang signifikan atau tidak terhadap disiplin kerja, dari hasil analisis data diperoleh nilai uji t sebagai berikut:

Berdasarkan hasil pengujian secara parsial pengaruh kepemimpinan terhadap disiplin kerja diperoleh thitung sebesar $-0,219<$ ttabel sebesar 1,996 dan mempunyai angka signifikan sebesar 0,827>0,05.berarti H0 diterima (Ha ditolak),Hal ini menunjukan bahwa tidak ada pengaruh yang signifikan antara kepemimpinan terhadap disiplin kerja pengawai Badan Lingkungan Hidup dan Kebersihan Kabupaten Aceh Tenggara.

\section{f. Kompensasi terhadap Disiplin kerja}

Uji t digunakan untuk mengetahui apakah kompensasi secara individual mempunyai hubungan yang signifikan atau tidak terhadap disiplin kerja,dari hasil analisis data diperoleh nilai t sebagai berikut:

Berdasarkan hasil pengujian secara parsial pengaruh kompensasi terhadap disiplin kerja diperoleh $\mathrm{t}_{\text {hitung }}$ sebesar $-1,849<\mathrm{t}_{\text {tabel }}$ sebesar 1,996 dan mempunyai angka signifikan sebesar $0,069>0,05$. Berarti $\mathrm{H}_{0}$ diterima $\left(\mathrm{H}_{\mathrm{a}}\right.$ ditolak), Hal ini menunjukan bahwa tidak ada pengaruh yang signifikan antara kompensasi terhadap disiplin kerja pengawai Badan Lingkungan Hidup dan Kebersihan Kabupaten Aceh Tenggara . 


\section{g. Uji Signifikansi Simultan (Uji F)}

Uji $F$ atau juga disebut juga dengan uji signifikansi serentak dimaksudkan untuk melihat kemampuan menyeluruh dari variabel bebas yaitu motivasi,Pendidikan dan pelatihan,kepemimpinan dan kompensasi untuk dapat menjelaskan tingkah laku atau keragaman disiplin kerja.Uji $\mathrm{F}$ juga dimaksudkan untuk mengetahui apakah semua variabel memiliki koefesien regresi sama dengan nol.Berikut adalah hasil statistic pengujiannya. maka dapat diketahui nilai perolehan uji $\mathrm{F}$ untuk hubungan antara Displin dan Beban Kerja terhadap Kinerja pengawai $F$ tabel $=n-k-1=68-4-1=63$ adalah 2,520 . Berdasarkan hasil ujian $F_{\text {hitung }}$ pada table di atas dapat nilai $F_{\text {hitung }} 220,636>F_{\text {tabel }} 2,520$ kemudian dilihat dengan hasil nilai probabilitas signifikan $0,000<0,05$, maka Ho ditolak dan (Ha diterima).Dari nilai tersebut maka dapat disimpulkan bahwa kepemimpinan dan kompensasi berpengaruh secara signifikan terhadap disiplin kerja pengawai Badan Lingkungan Hidup dan Kebersihan Kabupaten Aceh Tenggara.

\section{KESIMPULAN}

Dari hasil penelitian, dapat disimpulkan bahwa:

Berdasarkan hasil peneliti pada objek yang diteliti maka dapat permasalahan dalam penelitian ini faktor-faktor motivasi, pendidikan dan pelatihan, kepemimpinan, dan kompensasi mempengaruhi disiplin kerja pengawai pada Badan Lingkungan Hidup dan Kebersihan Kabupaten Aceh Tenggara. Tujuan penelitian adalah untuk menganalisis pengaruh motivasi, pendidikan dan pelatihan, kepemimpinan dan kompensasi terhadap disiplin kerja pada Badan Lingkungan Hidup dan Kebersihan Kabupaten Aceh Tenggara. Populasi dalam penelitian ini berjumlah 216 orang akan tetapi sampel yang diambil hanya 68 orang. Teknik pengumpulan data yang digunakan dalam penelitian ini dengan angket (questioner), interview (wawancara) dan studi dokumentasi. Teknik analisis data yang digunakan uji asumsi klasik yang meliputi uji normalitas,uji heteroskedastisitas dan uji autokorelasi, persamaan regresi dan pengujian tesis yaitu uji t parsial, uji f simultan dan koefesien determinasi. Berdasarkan hasil pengujian secara parsial pengaruh motivasi terhadap disiplin kerja diperoleh $t_{\text {hitung }}$ sebesar $-2,587<t_{\text {tebel }}$ sebesar 1,996 dan mempunyai angka signifikan sebesar sebesar 0,012 < 0,05 menunjukan bahwa ada pengaruh yang signifikan. pengaruh Pendidikan dan pelatihan terhadap disiplin kerja diperoleh $\mathrm{t}_{\text {hitung }}$ sebesar $6,356>\mathrm{t}_{\text {tabel }}$ sebesar 1,996 dan mempunyai angka signifikan sebesar $0,000<0,05$ menunjukan bahwa ada pengaruh yang signifikan.Pengaruh kepemimpinan terhadap disiplin kerja diperoleh $\mathrm{t}_{\text {hitung }}$ sebesar $-0,219<\mathrm{t}_{\text {tabel }}$ sebesar 0,827 $>0,05$ menunjukan bahwa tidak ada pengaruh yang signifikan. Pengaruh kompensasi terhadap disiplin kerja diperoleh $t_{\text {hitung }}$ sebesar $-1,849<\mathrm{t}_{\text {tabel }}$ sebesar 0,244 dan mempunyai angka signifikan sebesar 0,069 $>0,05$ menunjukan bahwa tidak ada pengaruh yang signifikan. Berdasarkan hasil uji $\mathrm{F}_{\text {hitung }} 220,636$ $>\mathrm{F}_{\text {tabel }} 2,52$ kemudian dilihat dengan hasil nilai probabilitas signifikan $0,000<0,05$, maka $\mathrm{H}_{0}$ ditolak dan $\mathrm{H}_{\mathrm{a}}$ diterima yang dapat bahwa Motivasi, pendidikan dan pelatihan, kepemimpinan dan Kompensasi berpengaruh secara signifikan terhadap disiplin kerja Badan Lingkungan Hidup dan Kebersihan Kabupaten Aceh Tenggara.

\section{REFERENSI}

Buku:

[1] Achmad Tohardi. 2002. Manajemen Sumber Saya Manusia, Cetakan Pertama, Bandung : CV. Mandar Maju

[2] Anwar, Supardi, S. 2004. Dasar-dasar Perilaku Organisasi, Yogyakarta: UII Press. Bismas (2007) dengan tujuan untuk mengetahui hubungan antara lingkungan psikologis terhadap kinerja 
karyawan di India dengan perilaku organisasi (Organization Citizenship Behavior) dan kepuasan kerja sebagai variable perantara.

[3] Borzaga dan Tortia. 2006. Dengan judul "Worker Motivation, Job Satisfaction, and Loyalty in Public and Nonfrofit Social Service". California. Available form : URL: http//proquest.umi.com/pqdweb

[4] Chen. 2004. Examining the Effect of Organization Culture and Leadership Behaviors an Organizational Commitment, Job Satisfaction and Job Performance at Small and Middle sized Firms of Taiwan. Economis Journal. Taiwan.

[5] Choiri, Muhammad dkk (2000). Judul : Faktor Individu dan Faktor Lingkungan Sebagai Pembentuk Perilaku Kerja Karyawan Serta Pengaruhnya Terhadap Kinerja Karyawan.

[6] Gorda, I Gusti Ngurah, 2006. Manajemen Sumber Daya Manusia. Cetakan Ketiga. Denpasar: Astabrata Bali.

[7] Handoko, T,H. 2001. Manajemen Personalia dan Sumber Daya Manusia. Yogyakarta : BPFE Press.

[8] Hasibuan, SP, M. 2007. Manajemen Sumber Daya Manusia, Edisi Revisi. Cetakan Kesepuluh. Jakarta : Bumi Aksara.

[9] Husein Umar, 2005. Riset Sumber Daya Manusia Dalam Organisasi, Cetakan Ketiga. Jakarta : PT. Gramedia Pustaka Utama.

[10] Istijanto. 2006. Riset Sumber Daya Manusia. Edisi kedua. Jakarta : PT. Gramedia Pustaka.

[11] Irmin, Suejitno. 2004. Hand out Untuk mengelola SDM. Cetakan Pertama. Yayasan : Seyma Media.

[12] Mahmudi, 2005. Manajemen Kinerja Sektor Publik Yogyakarta : UPP AMP YKPN.

[13] Mangkunegara, A.A. Anwar Prabu, 2006. Evaluasi Kinerja SDM. Cetakan Kedua. Bandung : PT. Refika Aditama.

[14] Marianti, Ni Putu Sri. 2007. Pengaruh Kepemimpinan Terhadap Disiplin dan Kinerja Dosen Universitas Warmadewa Denpasar. Tesis. Udayana : Magister Manajemen.

[15] Martoyo, Susilo. 2000. Manajemen Sumber Daya Manusia. Edisi Keempat. Yogyakarta : BPFE.

[16] Matthews, 2006. Searching for job satisfaction Survey City \& Guilds. Economic Journal. ISCO.

[17] Mawar (2007) tesis Magister Manajemen Universitas Udayana, dengan judulnya "Pengaruh Kompensasi, Pelatihan, Kepemimpinan, dan Lingkungan Kerja Terhadap Kinerja Pegawai di PT Askes (Persero) Kantor Cabang Denpasar".

[18] Neal dan Griffin (1999). Judul : Developing a Modal Individual Performance for Human Resource Management. Ranee Barnet dan Lisa Bradley (2007). Judul : The Impact of organization Support for Career Development on Career Statisfaction.

[19] Riduwan; Kuncoro Engkos Achmad. 2007. Cara Menggunakan dan Memaknai Analisis Jalur (Path Analisis). Cetakan Pertama. Bandung : Alfabeta.

[20] Rivai, Veithzal. 2005. Manajemen Sumber Daya Manusia Untuk Perusahaan dari Teori ke Praktek. Cetakan Pertama. Jakarta : PT. Raja Grafindo Persada.

[21] Robbins S,P. 2006. Perilaku Organisasi. Edisi Kesepuluh. Klaten : PT. Intan Sejati Klaten.

[22] Safari, Triantoro. 2004. Kepemimpinan. Cetakan pertama. Surabaya : CV. Graha Sejati Klaten. 
[23] Santoso, Singgih. 2004. Buku Latihan SPSS Statistik Multivariate. Cetakan Ketiga. Jakarta : PT. Elex Media Komputindo Kelompok Gramedia. bentuk organisasional dan mengnterviu divisi bisnis dan Acrospace di Eropa dari korporasi Fortune 100 (Aerospace Business Devision / ABD).

[24] Yukl, Gary. 2005. Kepemimpinan dalam Organisasi. Edisi Kelima. Jakarta : Prenhallindo. 